\title{
ラオス人民民主共和国ビエンチャン都におけるタイ肝吸虫症の現況
}

\author{
中 村哲 \\ 広島文化学園大学看護学部看護学科・大学院看護学研究科
}

\section{Present Situation of Opisthorchiasis in Vientiane Capital, Lao Peoples' Democratic Republic}

\author{
Satoshi NAKAMURA \\ Graduate School of Nursing and Faculty of Nursing, Hiroshima Bunka Gakuen University
}

\begin{abstract}
Opisthorchiasis is the commonest liver disease caused by Opisthorchis viverrini in Thailand, Lao People's Democratic Republic (PDR) and Cambodia, which will be a major cause of future human cholangiocarcinoma in these regions. In this short review, we describe the epidemic aspects of this parasite infection and the outline of results of our recent surveys of the fluke in humans and its intermediate hosts in Vientiane Capital, where information on the opisthorchiasis epidemic is insufficient. We examined the stool from a total of 296 persons living in the Phailom village (population, 1545, 1999) from 2011 to 2012. As a result, the intestinal parasitism rate was very high from 54 to $59 \%$. Among intestinal infections, $O$. viverrini infection was observed at highest rates from 51 to $53 \%$. On the other hand, the rate of infection by nematodes was very low. We also conducted intermediate-host investigations in the river and damp areas at 3 villages in the Vientiane capital and 2 villages in Vientiane Province in 2012. As shown by these results, no Opisthorchis species was detected in 147 samples of the host genus Bythinia. However, metacercariae were detected in 3 samples of Cyclocheilichthys sp. and in a Hampala sp. in 303 cyprinid fishes collected from the Haikham village area of Vientiane Capital.
\end{abstract}

Key words: Lao PDR（ラオス人民民主共和国), Vientiane Capital（ビエンチャン都), liver fluke（肝吸虫）, Opisthorchis viverrini（タイ肝吸虫）, Opisthorchiasis（タイ肝吸虫症）

\section{1. はじめに 一ラオスと吸虫症一 \\ ラオス人民民主共和国（以下ラオスと略す）は東南ア ジア大陸部に位置し, 時計回りに中華人民共和国 (中国), ベトナム人民民主共和国（ベトナム）, カンボジア王国 (カンボジア), タイ王国 (タイ), ミャンマー連邦共和 国の五カ国に囲まれた山岳国である。1975 年に成立し, 社会主義の体制をとる国家である。1980 年代後半にべ}

受付 2017 年 1 月 11 日，受理 2017 年 3 月 6 日

Reprint requests to: Satoshi NAKAMURA

Graduate School of Nursing and Faculty of Nursing, Hiroshima Bunka Gakuen University, 2-10-3, Aga Minami, Kure, Hiroshima 737-0004, Japan

E-mail: nakamura@hbg.ac.jp
トナム同様に資本主義経済を導入し，それまでの鎖国を 改め外国への門戸を開いた。国土 $\left(236,800 \mathrm{~km}^{2}\right)$ は日本 のほぼ本州に匹敵し，4月から9月にかけての雨季执よ び 10 月から 3 月までの乾季に分かれるモンスーン気候 に属している。国連による2016年での推計人口は扎よ そ680万，2010-2015 年での人口増加率は 1.7\%/ 年であ る(1)。ラオスは農業国であると同時に資源大国でもあ る。その経済は 2000 年以降，急速に上昇を続け，2020 年までに最貧国から脱することを目指している。世界銀 行（The World Bank）によると，2015 年時点での国民一 人頭の年間総収入 (GNI) は $1,740 \mathrm{US}$ ドル, 貧困率は 2012 年時点で $16.7 \%$ となっている。しかし，上下水道 や電気，道路などの生活基盤の整備が都市と農村部で極 端に異なっている。UNDPによる水の安全や保健医療を 
加味した 2014 年の人間開発指数 (Human Development Index: HDI）では 0.575 （参加 188 国中 141 位）となっ ている。

ラオスの千人出産当たりの乳児死亡率は 47 で，2014 年の死因の第一位は大動脈・心疾患である。しかし，上 位にはインフルエンザ・肺炎（第 3 位）やデング熱（第 4 位)，下痢症（第 7 位）など感染症が占めている (2)。 特に下痢症の中には本報告の主題となる吸虫による下痢 症も含まれている。

我々は 1999 年以降，経年的にラオス首都ビエンチャ ン近郊農村部に扣いて生活環境と下痢起因微生物を総合 的に調査し, 住民の下痢症発生に係る要因を明らかにす ること主目的として調査研究を行っている。この地域は ビエンチャン都の急激な経済発展の影響下にあり, 現在 急速に生活環境が変貌しつつある。しかし，その一方で 村民の間の健康問題として多く聞かれた消化管寄生虫 (現地ではメートーン：腹の虫, ラオスの医学用語では メーカファー: 寄生虫と言う）による疾患が残っている。

わが国では今日, 肺吸虫症や住血吸虫吸虫症, 肝吸虫 症など, 吸虫類が起因となる感染症を見出すことは困難 である。しかし, 対岸にある東アジアや東南アジア諸国 ではこの種の疾患 (3) が普通の感染症として存在し「雇 みられない熱帯病 (Neglected Tropical Diseases: NTD)」, あるいは単に「顧みられない感染症」として紹介されて いる。とはい光, この命名は私たちが生活する先進国 や経済的先進地域で感染症がコントロールされている 中に住む人々によるものであり, 今それらの疾患が存在 し，流行する地域に住む人々にとっては，真に対応が 必要とされている疾患に他ならない。特にタイ肝吸虫 (Opisthorchis viverrini: Ov) について述べれば，調査現 地ではその中間宿主となる魚種を生食する習慣があり， タイ肝吸虫症の蔓延が常態化している。また，同症は胆 管癌の要因の一つとして知られて打り (4), ラオス国の 胆管がんの予防対策としてもタイ肝吸虫症の対策は急務 である。これらのことから，本稿ではタイ肝吸虫症のラ オスでの研究の意義と我々が最近実施した Ovの中間宿 主に関わる共同研究について紹介する。

\section{2. 肝吸虫症の病因とその研究概要}

\section{1 肝吸虫症と研究の概要}

東アジア打よび東南アジアに扮いてヒトに感染し公衆 衛生上問題となる肝吸虫種はシナ肝吸虫（Clonorchis sinensis) と Ov で, 4,500 万人以上が曝露されている (5)。 シナ肝吸虫は 中国南部抒よびベトナム北部，台湾，韓 国の一部に限局し，Ovは主としてタイおよびラオス， カンボジア，ベトナム中部に分布している。

主題となる Ovの成体は体長が $10 \mathrm{~mm}$ 泀どで，ヒト胆 囊内に寄生する。虫卵は上端に扁平な蓋を有するつぼ型 で，その大きさは長径 $30 \times$ 短径 $7 \mu \mathrm{m}$ 内外と, 粪便中か ら検出される寄生虫卵としては最も小さいものの一つで ある(図 1a)。

Ovの生活環とその中間宿主（巻貝と魚）のヒト感染 に関わる役割について以下簡単にふれる。Ovのヒトへ の感染はその感染幼虫を有した淡水魚の生食を通じて起 こる。Ovの生活環においてヒトを含む哺乳動物が終宿 主となる。Ovは宿主の肝臓や胆囊に寄生し, その虫卵 は胆道を経て消化管に排泄されて糞便とともに水中に入 り, 虫卵から出たミラシディウムが第一中間宿主のマメ タニシの仲間 Bithynia 属の巻貝に感染する。貝の中で発 育した Ovはセルカリア（図 1b）として水中に出て，第 二中間宿主のコイ科（Cyprinidae）魚類の鰖や皮下，筋 肉内に付着あるいは侵入し被囊することで, メタセルカ リア（図 1c）として寄生する。そしてこの魚を終宿主 が生で摂取することで感染が成立する。

ラオスでは1929年に Bedier と Chesneauによって現ビ エンチャン都と南部のカムアン県ターケークで最初のタ イ肝吸虫症例が報告された（6）。1970年代に発刊された 病理学の教科書によれば，北部ルアンパバーンでの感染 率は低いものの, 南部のチャンパサックでは72\%以上で あり，ビエンチャンでは $50 \%$ であるとの疫学調査結果が 得られていた（7）。その後は政治的動乱期に入り，80 年 代後期に入るまで調査はなされていなかった。この間, 隣国のタイでは，ラオ人が多い東北部を中心に国を挙げ て Ov 感染症に対するプラジカンテルを用いた集団化学

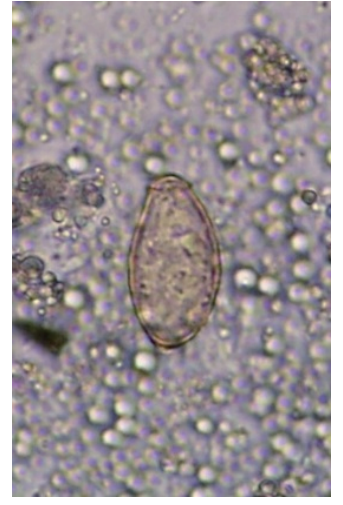

$\mathrm{a}$ 粪便中の虫卵

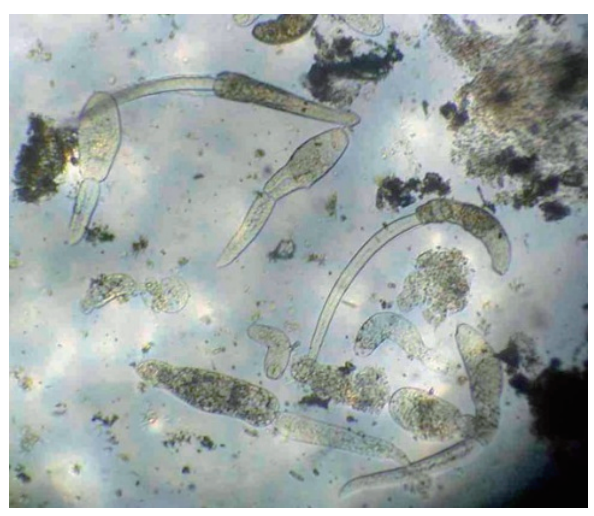

b 媒介貝中のセルカリア

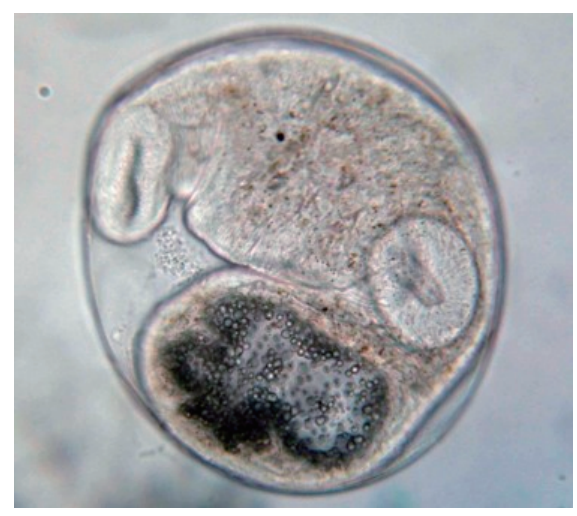

c メタセルカリア

図 1 タイ肝吸虫のステージ 
療法と予防キャンペーンを行っていた（8)。この運動は 効を奏したが，現在でも地域によっては70\%近くの住民 の Ov 感染が認めら机ている (8)。Ov 感染は今日では発 がん原因となることが知られ（8-10），1980-1981 年での Harinasuta ら（11）による調査以降に, この地域で胆管癌 が多発する原因となっている。一方ラオスでは，比較的 最近になって全国的な寄生虫調查が実施されタイ肝吸虫 症の全国分布が明らかになってきた。2002 年に実施さ れた全国的寄生虫調查（12）を含め, ラオスのビエンチャ ン都拉よびビエンチャン県を含む地域においては Ov の 寄生率が 30-50\% ときわめて高いことが判明している (13)。またラオス全体では 250 万人が感染していると推 計さ水ている (14)。Ov の地域調査の多くは中南部ラオ スで実施されており（15-17），ビエンチャン都近郊集落 の情報は学童を対象とした調查（18）を除いてほとんど 得られない。またこの地域での同吸虫の中間宿主の情報 も極めて少ないことから本調查を実施した(19:投稿中)。

\section{2 研究結果の概要}

\subsection{1 寄生虫調查}

2011 年及び 2012 年の 2 度にわたって消化管寄生虫検 查を被験者のインフォームドコンセントを得てカウン ターパート研究所であるラオス国立パスッール研究所と 共同で実施した。

調査地として，ラオスのビエンチャン都サイタニ郡パ イロム村を選定し， 2012 年打よび 2005 年に現地調査を 行った。この村落はビエンチャン都心から国道 13 号線 飞沿い約 $23 \mathrm{~km}$ 東北位置しており, 1999 年時点の人 口は 1,545 , 戸数は 211 であった。該村落を選定した理 由は, 寺を中心とした典型的なラオ・ルムの村落であり, その創立が非常に古く, また伝統的な生活様式が色濃く 残っていること, そして村落の自治組織が調査の受け入 れを承認したことによる。調査対象は 5 歳以上の任意参 加住民とし, 検便はフォルマリン・デタージェント法に よる沈降で寄生虫卵を回収し顕微鏡下で種を同定し，そ れぞれの種の 1 グラム当たりの虫卵 (Egg per gram: EPG）を算出した。2011 年の調査で得られたサンプル 144 例について $78(54.2 \%)$ の消化管寄生虫卵陽性例が 見られた。内訳は Ovが 73 例と最も多く, 9 割を占めた。 他は銁虫 (Hookworms), 条虫 (Taenia spp.), 回虫 (Ascaris lumbricoides), 暁虫(Enterobius vermicularis) がそれぞ れ 5 例と 3 例， 1 例， 1 例であった。

一方 2012 年の調査では得られたサンプル152例につい て 90 例 (59\%) の寄生虫卵陽性例が検出された。その内 訳は前年の調査とほぼ同じ傾向であった。Ovが 80 例と 最も多く, 括よそ9割を占めた。そ饥以外は鈎虫（Hookworms), 条虫 (Taenia spp), 回虫 (Ascaris lumbricoides),

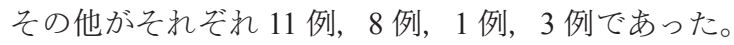

この 2 回の調查結果からパイロムでは都市近郊の村で ありながらタイ肝吸虫の感染率が他の消化管寄生虫に比 べて突出して高いことと, 線虫類の寄生が低い傾向が示 された。

\subsection{2 タイ肝吸虫の中間宿主調査}

Ovの中間宿主に関して, タイでは調査が多くなされ ている。この Ov 第二中間宿主魚類および第一中間宿主 である巻貝 Bythinia 属の種とその分布のラオスでの解明 は重要である。特にビエンチャン都内での魚類への Ov 感染についての報告はまだ知られていないことから，ラ オス国立パスッール研究所打よびタイ国立シラパコーン 大学理学部のカウンターパート研究者との共同研究とし て本調査を実施した。

Ov の中間宿主に関わる調査は 2012 年 11 月にビエン チャン都サイセタ郡のハイカム拉よびナックナイ, ナン ニェン, ビエンチャン県サントーン郡フェイカムと同郡 ナーホイの 5 村落の水域で実施した。採取した貝類およ び魚類はラオス拉よびタイのカウンターパート研究施設 に打いて, 寄生吸蝢を探査し, 同定した。貝類では光 源下でのセルカリア誘出法を実施した。魚類に関して は, 調査水域で採取または漁夫から直接購入したサン プルを用いた。鯺の周辺の組織を顕微鏡下で観察し, 吸 虫陽性個体については Ov 特異プライマーを用いた PCR を実施した。貝類は 6 科 10 属 11 種 564 個体, 魚類は コイ科に属する 491 個体を採取した。今回の調査ではナ ンニェン村で採取した Bithynia に属する 147 個体の貝の らち 2 個体から両生類の吸虫 (Loxogenoides bicolor) が 採取されたのみで, 他の貝類からは吸虫類は検出され なかった。魚類では八イカム村で得た 303 個体のうち, Cyclocheilichthys sp. 3 個体拈よび Hampala sp. の 1 個体 で Ov と考光られるメタセルカリアを検出した（表 1)。

\section{3 考察と課題}

ビエンチャン都圈地域のこの調査地区での消化管寄生 虫感染に関わる突出した Ov の感染率と他の線蝢の極 端な低率傾向はラオス国内の他の地域での重感染が多い 結果（15-17）とは異なっている。ビエンチャン都圈地域 では検便時に実施した質問紙調査からも同村居住者の寄 生虫の認知度は極めて高く, キャンペーンにも注意が払 われ，治療への認識も高いことが示唆されて拈り（未発 表), 自己治療も含めて比較的頻回に抗線虫薬が駆虫薬 として処方されていることを示しており，この地域の特 徵之考光られた。Ovを含を吸虫や条蝢には抗線虫薬 は効果がないからである。この Ov の感染率の高さは他

表 1 ビエンチャン都近郊域で採取したコイ科魚類とタイ肝吸 虫陽性個体

\begin{tabular}{lccc}
\hline \multicolumn{1}{c}{ 採取場所 } & 水域 & בイ科 & $\begin{array}{c}\text { タイ肝吸虫 } \\
\text { 陽性個体 }\end{array}$ \\
\hline サイセタ郡ハイカム & 河川, 湿地 & 303 & 4 \\
サイセタ郡ナックナイ & 池 & 0 & 0 \\
サイセタ郡ナンニェン & 池 & $154^{* *}$ & 0 \\
サントーン郡フェイカム* & 水田 & 17 & 0 \\
サントーン郡ナーホイ* & 河川 & 17 & 0 \\
\hline
\end{tabular}

*ビエンチャン県

**ビエンチャン県ナムグム郡産魚類 6 個体を含む 
のビエンチャン都の学童の調査でも示されている(18)。 しかし，Ovの感染率はタイでの事例を見てもこのまま では下がらないよらに考觉られる。その理由は村人が淡 水魚の生食を好むからである(20)。

ビエンチャン都圏域内での Ovの中間宿主（巻貝）に 関し，我々の調査と同時期に発表された Kiatsopit ら (2012）のタイとラオスでの貝の報告では，ビエンチャ ン県域での第一中間宿主である貝はBithynia siamensis と 同定している。その種類をほぼ同じ地域で 5,900 個のレ ベルで採取した結果からは感染率が東北タイ(コンケン) に比べて非常に高いことが判明している(21)。我々の 結果では十分な量の Bithynia 種の個体が得られなかった ことから今回確認はできなかった。一方，本研究では， ビエンチャン都圏で初めてタイでの中間宿主と同じ属 Cyclocheilichthys spp. および Hampara sp. を確認すること ができた（11）。このことから今後, 第一中間宿主の感 染率や魚種の確認, 分布, 魚種の発育ならびにメタセル カリア寄生の時期的な消長や住民の魚種の嗜好性等につ いて，さらに明らかにする必要がある。

ラオスでは肝吸虫症の実態は中間宿主のみならず，そ の寄生体の種類と分布も判然として抢らず，不明な事が まだ多い。本研究で魚類に寄生したセルカリアについて PCR を用いて確認した理由は，Ov 以外に近縁でヒト小 腸の寄生吸虫（Haplorchiidae, Heterophiidae など）に属 する他種の感染も知られているからである (22)。この ような寄生体の中間宿主の種類と分布や Ov 感染との関 係性，例えば中間宿主での感染に関わる干渉についても ラオスでは不明である。

ラオスではすでに肝がんが国民の死因の第 5 位となっ ている(2)。本稿の主題であるラオスの国民病と呼ぶべ きタイ肝吸虫症は，今後さらに胆管がん/肝がんの罹患 率に寄与すると予想され，その予防は国の保健問題の中 心となるかも知れない。このため, 吸虫類を含めた消化 管寄生虫感染予防対策を進める上で，地域内の中間宿主 の生態解明や住民の食習慣を考慮した対応が十分になさ れる必要がある。特に, ラオスの全国調査結果からは北 部山岳地域であるポンサリーやシェンクアン，ルアンプ ラバンでは他の地域に比べて感染率が低く(4.4-15.3\%), 調査対象が平地ラオ人と食習慣が異なる中・高地ラオ人 を多数含むものと見られる(13)。東北タイの事例では キャンペーン後の結果で見ても激減しているといらわけ ではない (23)。1990 年代の後半からラォスでは山岳民 族の平地への再定住化が図られて拈り，逆に平地ラオ人 の生食文化が一方では中・高地ラオ人の間に浸透してい くかも知れない (未発表資料)。貨幣経済の急速な浸透 による加工食品への依存や若年世代の食生活や食習慣が 変化し始めることによる食習慣伝播の阻害が起きること もある。この食習慣の変化は, 食品を媒介としたタイ肝 吸虫症の予防に確かにつながる意味で重要になると考光 られる。しかし，一方で伝統としての生食文化を積極的 に安全に残寸選択もあろら。例光ば，Ovのメタセルカ リアが感染した魚を凍結など物理的な手法で無害化する
技術や，清浄なコイ科淡水魚を自然の味覚に近い養殖で 提供する技術を開発するなどが考兄られる。人々が積極 的に拈いしいものを安全に食べることを考光るのが予防 医学たる衛生学の立場であろら。そのために魚類を安全 に養殖することや，食品の味を変化させること無く生食 を安全に提供することなどが考えられる。たとえばアニ サキス予防のため，すしネタを凍結した際の官能テスト 結果 (24) などの研究がさらに工夫され, 安全な食品の 提供に応用されるべきである。

\section{3. おわりに}

我々のこれまでの調査からは中部山岳地ラオス人（ラ オ・トゥン）や高地山岳ラオス人（ラオ・スーン）は生 食をせず，Ovの感染が少ないことがわかっている（25）。 Ovの感染は低地ラオス人（ラオ・ルム）の生食文化と 強くかかわっている。調査を行ったラオスの農村やそれ を取り巻く湿潤環境は下水が処理されることなく污染さ れることから，確かに衛生的とはいえない。Ovのライ フサイクルにはこのよらな環境に生息する第一中間宿主 である巻貝の存在が必要である。その存在下でユイ科の 幼魚は村が雨季にメコンやその支流の氾濫原となる時に 感染が成立する。しかし，これらの魚は村の中の水田や 池や湿地帯で捕れ，ラオスの人々にとって最も身近で美 味な食品なのである（20)。このよらに寄生虫疾患は Ov ひとつをとっても，予防対策からみた地域の人々の生活 習慣と嗜好性および媒介動物となる中間宿主の環境内で の動態，寄生体が宿主内で引き起こす発がん作用など， 過去の感染症ではなく，我々の目前にある，今日的疾患 に他ならない。

ラオスでは隣国タイでの Ov 対策の経験をいかした疾 病対策を引き継ぐことができると期待される。しかし， がん情報の国家レベルでの収集システムに寄生虫対策を 組み込むなどの Ov 感染に関する全国的な感染に関わる 情報の收集が急務であると同時に強固な経済基盤に支援 された，発がんのリスクを考慮した駆虫対策を構築する 必要がある。そのためには肝吸虫症が見られた地域や国 の研究機関，政策の実務家の間との交流が今後益々重要 になるものと考㝋られる。

\section{謝辞}

故 松田肇博士，波部重久博士，高木映博士（地球環 境学研究所), 中津雅美博士（国立国際医療研究セン ター), Dr. Somchai Lorvongseng (National Mahosot Hospital, Lao PDR), Dr. Phompadith Khattignavong (Institut Pasteur du Laos), Dr. Eng Sayavong (Ministry of Health, Lao PDR), Dr. Paul T. Brey (Institut Pasteur du Laos), Pr.Dr. Duangduen Krailas (Silpakorn University, Kingdom of Thai) の協力に感謝いたします。また現地調査を支えていた だいた故 Rattanaphorne Phetsouvanh 博士にこの場を借 りて深謝いたします。本研究は, 日本学術振興会科学 
研究費補助金（基盤 A，22256003）の助成を受けて行わ 机た。

\section{利益相反なし}

\section{文献}

( 1 ) UN data A world of information, Lao People's Democratic Republic. http://data.un.org/CountryProfile.aspx?crName= Lao\%20People\%27s\%20Democratic\%20Republic（2016 年 12 月 30 日アクセス)

( 2 ) WORLD HEALTH RANKING, HEALTH PROFILE: LAOS. http://www.worldlifeexpectancy.com/country-healthprofile/laos（2016 年 12 月 30 日アクセス）

( 3 ) Sripa B, Kaewkes S, Intapan PM, Maleewong W, Brindley PJ. Food-Borne Trematodiases in Southeast Asia: Epidemiology, Pathology, Clinical Manifestation and Control. In: Zhou XN, Bergquist R, Olveda R, Utzinger J (eds), Important Helminth Infections in Southeast Asia: Diversity and Potential for Control and Elimination, Part A, Advances in Parasitology Volume 72, 2010, 305-350.

( 4 ) Sripa B, Pairojkula C. Cholangiocarcinoma: Lessons from Thailand. Curr Opin Gastroenterol 2008;24:349-356.

( 5 ) Zheng S, Zhu Y, Zhao Z, Wu Z, Okanurak K, Lv Z. Liver fluke infection and cholangiocarcinoma: a review. Parasitol Res 2016;116:11-19.

(6) Bedier E, Chesneau P. Distomatose hepatique a Opisthorchis in Laos (Vientiane and Thakek). Bull Soc Path Exot 1929;22:331-334.

( 7 ) Sicard D, Jaeck D, Vannareth T. Pathologie lao. Mission de coopération culturelle et technique près l'Ambassade de France en République démocratique populaire lao, Ambassade de France, 1977, 224 p.

( 8 ) Sripa B, Bethony JM, Sithithaworn P, Kaewkes S, Mairiang E, Loukas A, Mulvenna J, Laha T, Hotez PJ, Brindley PJ. Opisthorchiasis and Opisthorchis-associated cholangiocarcinoma in Thailand and Laos. Acta Trop 2011;120 (Suppl 1):S158-S168.

( 9 ) http://monographs.iarc.fr/ENG/Classification/Classifications GroupOrder.pdf

(10) Sripa B, Deenonpoe R, Brindley PJ. Co-infections with liver fluke and Helicobacter species: A paradigm change in pathogenesis of opisthorchiasis and cholangiocarcinoma? Parasitol Int 2016; pii: S1383-5769(16)30484-6. doi: 10.1016/j.parint.2016.11.016.

(11) Harinasuta C, Harinasuta T. Opisthorchis viverrini: life cycle, intermediate hosts, transmission to man and geographical distribution in Thailand. Arzneimittelforschung 1984;34(9B):1164-1167.

(12) Rim HJ, Chai JY, Min DY, Cho SY, Eom KS, Hong SJ, Sohn WM, Yong TS, Deodato G, Standgaard H, et al. Prevalence of intestinal parasite infections on a national scale among primary schoolchildren in Laos. Parasitol Res 2003;91:267-272.
(13) Eom KS, Yong TS, Sohn WM, Chai JY, Min DY, Rim HJ, Jeon HK, Banouvong V, Insisiengmay B, Phommasack B. Prevalence of Helminthic Infections among Inhabitants of Lao PDR. Korean J Parasitol 2014;52:51-56.

(14) Keiser J, Utzinger J. Emerging foodborne trematodiasis. Emerg Infect Dis 2005;11:1507-1514.

(15) Kobayashi J, Vannachone B, Sato Y, Manivong K, Nambanya S, Inthakone S. An epidemiological study on Opisthorchis viverrini infection in Lao villages. Southeast Asian J Trop Med Public Health 2000;31:128-132.

(16) Sayasone S, Odermatt P, Phoumindr N, Vongsaravane X, Sensombath V, Phetsouvanh R, Choulamany X, Strobel M. Epidemiology of Opisthorchis viverrini in a rural district of southern Lao PDR. Trans R Soc Trop Med Hyg 2007; 101:40-47.

(17) Phongluxa K, Xayaseng V, Vonghachack Y, Akkhavong K, van Eeuwijk P, Odermatt P. Helminth infection in southern Laos: high prevalence and low awareness. Parasit Vectors 2013;6(1):328. doi: 10.1186/1756-3305-6-328.

(18) Phathammavong P, Moazzam A, Xaysomphoo D, Phengsavanh A, Kuroiwa C. Parasitic infestation and nutritional status among schoolchildren in Vientiane, Lao PDR. J Paediatr Child Health 2007;43:689-694.

(19) Lorvongseng S, Kattignavong P, Sayavong E, Habe S, Matsuda H, Midorikawa Y, Suzuki K, Midorikawa K, Brey PT, Nakatsu M, Nakamura S. Influence of parasitological investigation amongst villagers in Vientiane capital, Lao PDR. (in submission)

（20）高木 映，緒方悠香，田中裕教，黒倉 壽，中村 哲. ラオス打ける伝統的な淡水魚食品の加工方法一ヴィ エンチャン市の家庭から見る食文化の変容一。農学国 際協力 2012;12:26-33.

(21) Kiatsopit N, Sithithaworn P, Saijuntha W, Boonmars T, Tesana S, Sithithaworn J, Petney TN, Andrews RH. Exceptionally high prevalence of infection of Bithynia siamensis goniomphalos with Opisthorchis viverrini cercariae in different wetlands in Thailand and Lao PDR. Am J Trop Med Hyg 2012;86:464-469.

(22) Giboda M, Ditrich O, Scholz T, Viengsay T, Bouaphanh S. Current status of food-borne parasitic zoonoses in Laos. Southeast Asian J Trop Med Public Health 1991;Suppl: 56-61.

(23) Jongsuksuntigul P, Imsomboon T. The impact of a decade long opisthorchiasis control program in northeastern Thailand. Southeast Asian J Trop Med Public Health 1997; 28:551-557.

(24) Iwata K, Fukuchi T, Yoshimura K. Is the quality of sushi ruined by freezing raw fish and squid? A randomized double-blind trial with sensory evaluation using discrimination testing. Clin Infect Dis 2015;60:43-48.

(25) Midorikawa Y, Midorikawa K, Sangsomsack B, Phoutavan $\mathrm{T}$, Chomlasak K, Watanabe T, Vannavong N, Habe S, Nakatsu M, Kosaka Y, et al. Water, Livelihood and Health in Attapeu Province in Lao PDR. Southeast Asian Studies 2010;47:478-498. 